\title{
Sphingomonas kaistensis sp. nov., a novel alphaproteobacterium containing pufLM genes
}

Correspondence

Jörg Overmann

j.overmann@Irz.uni-muenchen.de

\author{
Myung Kyum Kim, ${ }^{1,2}$ Karin Schubert, ${ }^{2}$ Wan-Taek Im, ${ }^{1}$ Kyung-Ho Kim, ${ }^{1}$ \\ Sung-Taik Lee ${ }^{1}$ and Jörg Overmann ${ }^{2}$
}

\author{
${ }^{1}$ Environmental and Molecular Microbiology Laboratory, Department of Biological Sciences, \\ Korea Advanced Institute of Science and Technology (KAIST), 373-1 Guseong-dong, \\ Yuseong-gu, Daejeon 305-701, South Korea \\ ${ }^{2}$ Department Biologie I, Fakultät für Biologie, Ludwig-Maximilians-Universität München, \\ Maria-Ward-Strasse 1a, D-80638 München, Germany
}

Based on the current classification, the Sphingomonadales represents one of the six orders of the Alphaproteobacteria and includes the single family Sphingomonadaceae (Yabuuchi \& Kosako, 2005). Bacteria of the order Sphingomonadales are characterized by glucuronosyl ceramide and 2-OH myristic acid or non-hydroxy myristic acid, which replace the lipopolysaccharides of the Gram-negative cell wall. They contain octadecenoic acid $\left(\mathrm{C}_{18: 1} \omega 7 c, \mathrm{C}_{18: 1} \omega 9 t\right)$ as the major non-polar fatty acid and ubiquinone Q-10 as the major respiratory quinone.

Members of the Sphingomonadaceae have been repeatedly reclassified and presently comprise the six chemo-organotrophic genera Sphingomonas, Sphingobium, Sphingopyxis,

Abbreviations: BChl a, bacteriochlorophyll a; FAME, fatty acid methyl ester.

The GenBank/EMBL/DDBJ accession numbers for the 16S rRNA gene sequences of strains PB56 $^{\top}$, PB180 and PB229 are respectively AY769083, AY769084 and AY785128.

Details of the analysis of the carotenoids of the novel strains are available in a supplementary figure and table with the online version of this paper.
Sphingosinicella, Novosphingobium and Zymomonas and six genera of aerobic anoxygenic phototrophic bacteria, Blastomonas, Erythrobacter, Erythromicrobium, Porphyrobacter, Sandaracinobacter and Sandarakinorhabdus. 'Lutibacterium' and 'Citromicrobium' represent two additional lineages (Takeuchi et al., 2001; Yabuuchi \& Kosako, 2005; Gich \& Overmann, 2006).

In an attempt to assess the diversity of aerobic phototrophic bacteria systematically, we isolated a large number of red-, orange- and yellow-pigmented bacteria from surface soil collected on the campus of the Korea Advanced Institute of Science and Technology (KAIST) in Daejeon city, South Korea. After collection, $1 \mathrm{~g}$ soil was suspended in distilled water and serially diluted $(1: 10)$ three times. Aliquots $(100 \mu \mathrm{l})$ of each dilution were spotted on 10-fold-diluted R2A agar (Difco) plates and the plates were incubated at $25^{\circ} \mathrm{C}$. Isolated strains were also subcultured on undiluted R2A medium. For screening of the isolates, the pufL and pufM genes, which encode the typical type II photosynthetic reaction centre of proteobacteria, were amplified and sequenced as described by Nagashima et al. (1997). Of over 300 isolates, about 100 were found to contain the pufL and 
pufM genes. The three orange-red-pigmented strains $\mathrm{PB}^{5} 6^{\mathrm{T}}$, PB180 and PB229 were chosen for detailed characterization and were found to represent a novel lineage among the Sphingomonadaceae.

For an initial phylogenetic characterization, chromosomal DNA was extracted and purified using the DNeasy Tissue kit (Qiagen). PCR amplification of 16S rRNA genes and direct sequencing of the purified PCR products were performed as described previously (Yoon et al., 1997, 1998), thereby obtaining the almost-complete (i.e. 1393-1421 nt) 16S rRNA gene sequences of the strains. The $16 \mathrm{~S}$ rRNA gene sequences of the closest relatives were retrieved by a BLAST search (Altschul et al., 1997) and the sequences were aligned with the CLUSTAL_X program (Thompson et al., 1997). Evolutionary distances were then calculated using the Kimura two-parameter model (Kimura, 1983) and a phylogenetic tree was constructed by neighbour joining (Saitou \& Nei, 1987) in MEGA version 2.1 (Kumar et al., 2001) with bootstrap values based on 1000 replications (Felsenstein, 1985).

Based on the phylogenetic analysis (Fig. 1), strains PB56 ${ }^{\mathrm{T}}$, PB180 and PB229 are most closely related to species of the genus Sphingomonas, but form a distinct lineage which is supported by a bootstrap value of $100 \%$. The closest relatives of strain $\mathrm{PB}^{\mathrm{T}}{ }^{\mathrm{T}}$ are Sphingomonas oligophenolica JCM $12082^{\mathrm{T}}$ (95.8 \% 16S rRNA gene sequence similarity), Sphingomonas koreensis KCTC $2882^{\mathrm{T}}(95.1 \%)$, Sphingomonas mali IFO $15500^{\mathrm{T}}(95.1 \%)$, Sphingomonas faeni DSM $14747^{\mathrm{T}}$ (94.8\%), Sphingomonas pruni IFO $15498^{\mathrm{T}}(94.7 \%)$, and Sphingomonas aquatilis KCTC $2881^{\mathrm{T}}(94.6 \%)$. Although the 16S rRNA gene sequences of Sphingosinicella microcystinivorans $\mathrm{Y}^{\mathrm{T}}$ and Sphingosinicella xenopeptidilytica $3-2 \mathrm{~W} 4^{\mathrm{T}}$ also showed rather high similarity (95.0-95.2\%), the three new isolates clustered with members of the genus Sphingomonas. This branching pattern was clearly supported by our bootstrap analysis (Fig. 1). Lower sequence similarities were found with the other described Sphingomonas species $(<94.6 \%)$ and with Sandaracinobacter sibiricus $(92.3 \%)$. The values of $16 \mathrm{~S}$ rRNA gene sequence similarity suggest that the isolated strains represent a novel bacterial species within the genus Sphingomonas. The closest phylogenetic relatives listed above were selected for subsequent comparisons of physiological and biochemical features (Tables 1 and 2).

The $\mathrm{G}+\mathrm{C}$ content of the genomic DNA was determined using HPLC after enzymic degradation of the DNA to nucleosides (Mesbah et al., 1989; Tamaoka \& Komagata, 1984). Genomic DNA of strains PB56 ${ }^{\mathrm{T}}, \mathrm{PB} 180$ and PB229 had a G $+C$ content between 69.1 and $69.9 \mathrm{~mol} \%$ (Table 1), whereas the G $+\mathrm{C}$ content of all Sphingomonas species described to date ranges between 59 and $67 \mathrm{~mol} \%$ (Yabuuchi et al., 2002).

The 16S rRNA gene sequence similarities between the three strains $\mathrm{PB}_{56}{ }^{\mathrm{T}}, \mathrm{PB} 180$ and $\mathrm{PB} 229$ were $98.6-98.8 \%$. DNADNA hybridization was performed in five replicates by the fluorometric method of Ezaki et al. (1989). The DNA-DNA hybridization values between strains $\mathrm{PB} 56^{\mathrm{T}}$ and $\mathrm{PB} 180$ were $67.7 \pm 11.7 \%$ and those between strains $\mathrm{PB}^{\mathrm{T}}{ }^{\mathrm{T}}$ and $\mathrm{PB} 229$ were $73.1 \pm 5.0 \%$. Based on the commonly accepted criteria for the delineation of a bacterial species $(\geqslant 70 \%$ DNA-DNA hybridization and $\geqslant 97 \% 16 \mathrm{~S}$ rRNA gene sequence similarity; Rosselló-Mora \& Amann, 2001), and considering the values of the standard deviations, the three isolated strains represent members of a single species.

All three strains formed orange-red, circular, convex and smooth colonies. As observed by phase-contrast microscopy (Zeiss Axiostar Plus), cells grown for 4 days at $25^{\circ} \mathrm{C}$ in R2A broth were non-motile rods, $0.7 \mu \mathrm{m}$ wide and $1.1 \mu \mathrm{m}$ long. Cells were Gram-negative as determined by the $\mathrm{KOH}$ method (Buck, 1982), oxidase-positive (determined by oxidation of $1 \% p$-aminodimethylaniline oxalate) and catalase-positive (determined by gas production upon addition of $3 \% \mathrm{H}_{2} \mathrm{O}_{2}$ ). Growth was obligately aerobic. Reduction of nitrate and production of indole was not observed. The optimum temperature for growth on R2A agar was $25-30^{\circ} \mathrm{C}$. The strains did not require any vitamins. They did not grow on MacConkey agar (Difco) and only strain PB180 grew readily on nutrient agar at $25^{\circ} \mathrm{C}$ (Table 1).

Substrate utilization was assessed with the API 20NE and API 32GN systems and enzyme activities were assessed with the API ZYM microtest system according to the recommendations of the manufacturer (bioMérieux). For reference, we chose the type strains of the five most closely related Sphingomonas species (see above) and Sphingosinicella microcystinivorans $\mathrm{Y}^{\mathrm{T}}{ }^{\mathrm{T}}$. In addition, the type strains of the four orange-pigmented species Sphingomonas abaci, Sphingomonas aerolata, Sphingomonas aurantiaca and Sphingomonas roseiflava were included in this comparison. The three newly isolated strains utilized D-glucose, L-rhamnose, $\mathrm{N}$-acetylglucosamine, D-mannitol, 4-hydroxybenzoate, L-proline, L-serine and glycogen. In addition, L-arabinose, maltose, mannose, malate, malonate, adipate, caprate and salicin were utilized by individual strains. Of the enzymes tested, alkaline phosphatase, esterase (C4), esterase lipase (C8), leucine arylamidase and trypsin were present (Table 1). The three novel isolates differ from most of their closest phylogenetic relatives by the capacity to use D-mannitol, L-serine and 4-hydroxybenzoate, the poor utilization of gluconate and by the lack of $\beta$-glucosidase (aesculin hydrolysis) and $\beta$-galactosidase and the lack of growth on tryptic soy agar (Table 1).

For the analysis of fatty acids, the three strains were cultivated for 4 days at $25^{\circ} \mathrm{C}$ on R2A agar. The cell mass was saponified and fatty acid methyl esters (FAMEs) were methylated and then extracted according to the protocol of the Sherlock Microbial Identification System (MIDI, Inc.). Fatty acids were analysed by gas chromatography (Hewlett Packard 6890) and identified by the Microbial Identification software package (Sasser, 1990). 


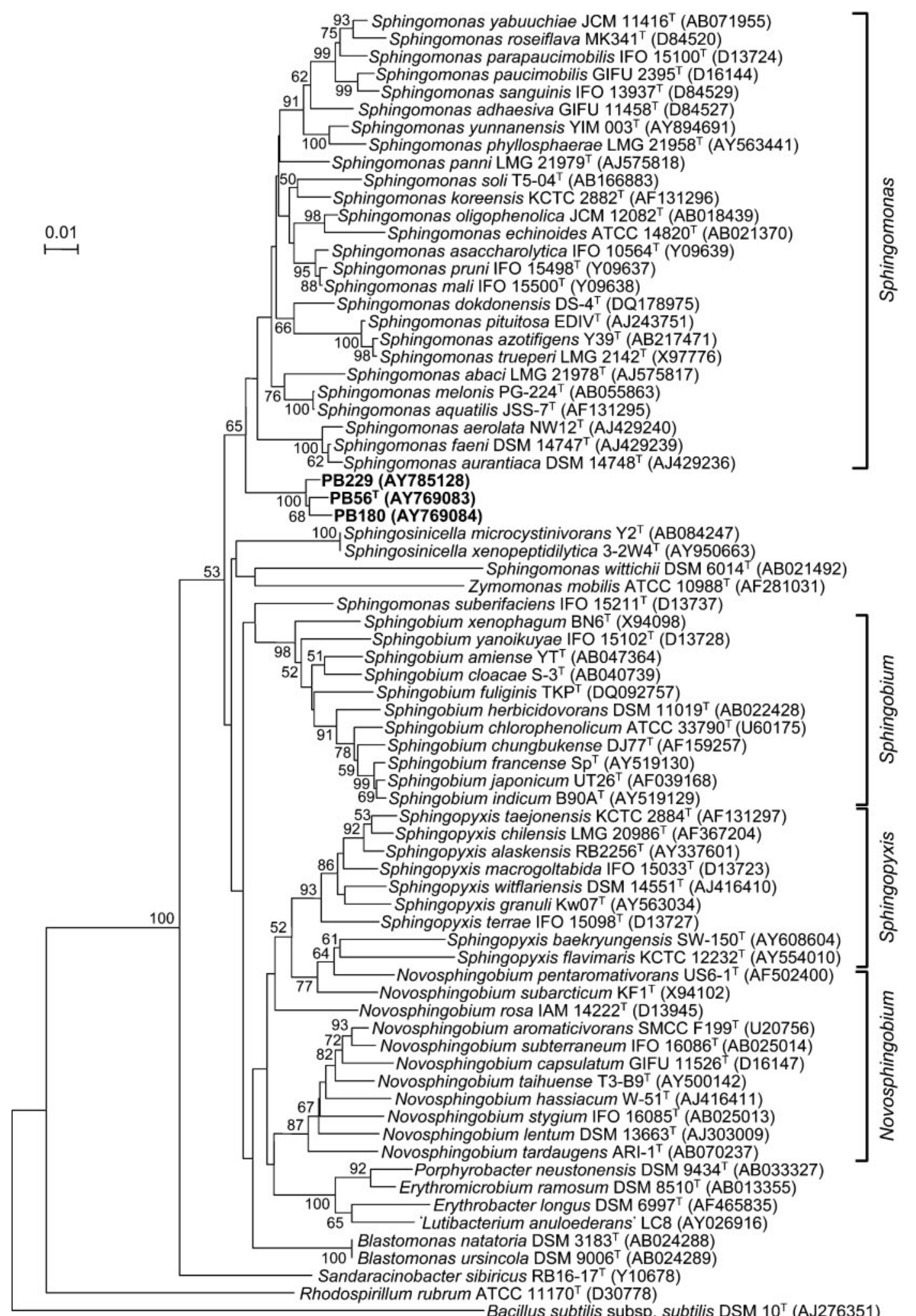

Fig. 1. Neighbour-joining tree showing the phylogenetic positions of strains $P B 56{ }^{\top}, P B 180$ and PB229 and other related taxa based on 16S rRNA gene sequences. Bar, 0.01 substitutions per nucleotide position. Numbers at nodes give bootstrap values for each node out of 100 bootstrap resamplings (only values $>50$ are shown). 
Table 1. Biochemical and chemotaxonomic characteristics of strains PB56 ${ }^{\top}, \mathrm{PB} 180$ and $\mathrm{PB} 229$ and related taxa

Strains: 1, PB56 ; 2, PB180; 3, PB229; 4, Sphingosinicella microcystinivorans (three strains) (data from Maruyama et al., 2006); 5, Sphingomonas abaci $\mathrm{C} 42^{\mathrm{T}}$ (Busse et al., 2005); 6, Sphingomonas aerolata (three strains) (Busse et al., 2003); 7, Sphingomonas aurantiaca (three strains) (Busse et al., 2003); 8, Sphingomonas faeni DSM $14747^{\mathrm{T}}$ (Busse et al., 2003); 9, Sphingomonas aquatilis KCTC 2881 ${ }^{\mathrm{T}}$ (Lee et al., 2001); 10, Sphingomonas koreensis (two strains) (Lee et al., 2001); 11, Sphingomonas mali (three strains) (Takeuchi et al., 1995); 12, Sphingomonas pruni (three strains) (Takeuchi et al., 1995); 13, Sphingomonas oligophenolica S213 ${ }^{\mathrm{T}}$ (Ohta et al., 2004); 14, Sphingomonas roseiflava IAM $14823^{\mathrm{T}}$ (Yun et al., 2000). All strains tested, including PB56 ${ }^{\mathrm{T}}$, PB180 and PB229, were positive for catalase and the presence of sphingolipids and negative for indole production, urease and assimilation of 5-ketogluconate and phenylacetate. Positive results were obtained for strains $\mathrm{PB}_{6}{ }^{\mathrm{T}}, \mathrm{PB} 180$ and PB229 for the following tests, but no data are available for the other strains: utilization of L-proline and glycogen, growth on R2A and presence of alkaline phosphatase, esterase (C4), esterase lipase (C8), leucine arylamidase and trypsin. Negative results were obtained for strains PB56 ${ }^{\mathrm{T}}, \mathrm{PB} 180$ and PB229 for the following tests, with no data available for the other strains: utilization of 2-ketogluconate, L-alanine, propionate and valerate, growth on MacConkey agar and activity of lipase (C14), $N$-acetyl- $\beta$-glucosaminidase, $\alpha$-fucosidase, $\alpha$-galactosidase, $\alpha$-mannosidase and $\beta$-glucuronidase. ++ , Strongly positive; + , all strains positive; - , all strains negative; $\mathrm{V}$, variable among strains of one species; $\mathrm{W}$, weakly positive; ND, no data.

\begin{tabular}{|c|c|c|c|c|c|c|c|c|c|c|c|c|c|c|}
\hline Characteristic & 1 & 2 & 3 & 4 & 5 & 6 & 7 & 8 & 9 & 10 & 11 & 12 & 13 & 14 \\
\hline Motility & - & - & - & + & - & + & + & + & + & + & + & + & - & $\mathrm{ND}$ \\
\hline Cell length $(\mu \mathrm{m})$ & 1.5 & 0.7 & 1.5 & $0.6-1.0$ & $1.5-3.0$ & $1.5-2.6$ & $1.0-2.7$ & $2.0-2.6$ & $\mathrm{ND}$ & $\mathrm{ND}$ & ND & $\mathrm{ND}$ & $1.0-1.5$ & $\mathrm{ND}$ \\
\hline Cell width $(\mu \mathrm{m})$ & 1.0 & 0.5 & 1.0 & $0.3-0.7$ & $0.4-0.5$ & $0.6-0.8$ & $0.6-0.8$ & $0.6-0.8$ & $\mathrm{ND}$ & $\mathrm{ND}$ & ND & ND & $0.4-0.6$ & ND \\
\hline Colony colour ${ }^{\star}$ & PR & PR & PR & Y & $\mathrm{O}$ & $\mathrm{O}$ & $\mathrm{O}$ & $\mathrm{O}$ & $\mathrm{Y}$ & $\mathrm{Y}$ & $\mathrm{Y}$ & $\mathrm{Y}$ & $\mathrm{Y}$ & PY \\
\hline Oxidase & + & + & + & + & - & + & + & + & + & + & ND & ND & + & + \\
\hline Reduction of nitrate & - & - & - & - & ND & - & - & - & - & - & - & - & + & + \\
\hline $\begin{array}{l}\text { Production of acid from glucose } \\
\text { Enzyme activities }\end{array}$ & $\mathrm{W}$ & \multirow{2}{*}{\multicolumn{8}{|c|}{ Enzyme activities }} & - & - & W & - & - \\
\hline $\begin{array}{l}\text { Enzyme activities } \\
\text { Protease (gelatin hydrolysis) }\end{array}$ & - & - & - & - & & - & - & - & & & & & & \\
\hline$\beta$-Galactosidase (PNPG hydrolysis) & - & - & - & - & + & + & $\mathrm{w}$ & $\mathrm{w}$ & + & + & + & + & ND & $\mathrm{ND}$ \\
\hline$\alpha$-Glucosidase (aesculin hydrolysis) & - & - & - & - & + & + & + & + & - & - & + & + & $\mathrm{ND}$ & + \\
\hline \multicolumn{15}{|l|}{ Assimilation of: } \\
\hline Acetate & - & - & - & ND & ND & + & + & + & $\mathrm{ND}$ & $\mathrm{ND}$ & - & $\mathrm{W}$ & + & $\mathrm{ND}$ \\
\hline Adipate & + & - & - & - & ND & $\mathrm{W}$ & $\mathrm{W}$ & $\mathrm{W}$ & - & - & + & - & ND & $\mathrm{W}$ \\
\hline Caproate & - & - & + & - & ND & $\mathrm{ND}$ & ND & $\mathrm{ND}$ & + & - & - & - & ND & ND \\
\hline Citrate & - & - & - & + & - & ND & ND & + & - & - & - & - & - & + \\
\hline Gluconate & $\mathrm{W}$ & - & $\mathrm{W}$ & - & $\mathrm{W}$ & + & + & + & - & - & + & + & + & + \\
\hline DL-Lactate & - & - & - & ND & - & $\mathrm{V}$ & + & + & $\mathrm{ND}$ & $\mathrm{ND}$ & - & - & + & $\mathrm{ND}$ \\
\hline Malate & + & - & - & - & ND & $\mathrm{V}$ & + & - & - & + & - & $\mathrm{w}$ & - & + \\
\hline Malonate & - & - & + & $\mathrm{ND}$ & ND & $\mathrm{ND}$ & $\mathrm{ND}$ & - & - & - & - & - & - & $\mathrm{ND}$ \\
\hline 4-Hydroxybenzoate & + & + & + & $\mathrm{ND}$ & ND & - & $\mathrm{V}$ & - & $\mathrm{ND}$ & - & - & - & + & $\mathrm{ND}$ \\
\hline Propionate & - & - & - & ND & ND & - & $\mathrm{V}$ & + & $\mathrm{ND}$ & $\mathrm{ND}$ & - & - & ND & - \\
\hline L-Arabinose & - & - & + & - & - & + & + & + & + & - & $\mathrm{W}$ & + & + & + \\
\hline D-Glucose & + & + & + & - & - & + & + & + & + & + & + & + & + & + \\
\hline Maltose & + & - & + & - & - & + & + & + & + & + & + & + & + & $\mathrm{ND}$ \\
\hline D-Mannose & + & - & $\mathrm{W}$ & - & - & + & + & + & - & - & + & + & + & $\mathrm{W}$ \\
\hline D-Melibiose & - & - & + & ND & ND & $\mathrm{V}$ & + & + & - & + & + & $\mathrm{w}$ & ND & $\mathrm{ND}$ \\
\hline L-Rhamnose & ++ & + & ++ & ND & - & - & - & + & + & + & + & + & ND & - \\
\hline Sucrose & - & - & + & ND & - & + & + & + & + & + & + & + & ND & $\mathrm{ND}$ \\
\hline D-Mannitol & + & + & + & - & ND & - & - & - & $\mathrm{ND}$ & $\mathrm{ND}$ & - & - & ND & $\mathrm{ND}$ \\
\hline D-Sorbitol & - & - & + & ND & ND & - & - & - & - & - & - & - & ND & - \\
\hline$N$-Acetylglucosamine & + & + & ++ & - & - & + & + & + & + & + & + & + & ND & - \\
\hline Salicin & - & + & + & ND & ND & + & + & + & + & + & + & + & ND & $\mathrm{ND}$ \\
\hline L-Serine & + & + & + & ND & ND & - & - & - & $\mathrm{ND}$ & + & - & - & ND & $\mathrm{ND}$ \\
\hline L-Histidine & - & - & - & ND & - & - & - & - & - & + & - & - & - & $\mathrm{ND}$ \\
\hline DNA G $+\mathrm{C}$ content $(\mathrm{mol} \%)$ & 69.9 & 69.9 & 69.1 & $63.6-63.7$ & ND & 65.4 & 64.7 & 63.1 & 63.0 & 66.0 & $65.4-65.9$ & 65.4 & 64.2 & 67.2 \\
\hline
\end{tabular}

${ }^{*} \mathrm{O}$, Orange; PR, pink-red; PY, pink-yellow; Y, yellow. 
Table 2. Cellular fatty acid profiles of the novel isolates in comparison with closely related species of the order Sphingomonadales

Strains: $1, \mathrm{~PB}^{\mathrm{T}}{ }^{\mathrm{T}} ; 2, \mathrm{~PB} 180 ; 3, \mathrm{~PB} 229 ; 4$, Sphingosinicella microcystinivorans $\mathrm{Y}^{\mathrm{T}}$ (data from Maruyama et al., 2006); 5, Sphingomonas oligophenolica S213 ${ }^{\mathrm{T}}$ (Ohta et al., 2004); 6, Sphingomonas koreensis (mean values for two strains) (Lee et al., 2001); 7, Sphingomonas faeni DSM $14747^{\mathrm{T}}$ (Busse et al., 2003); 8, Sphingomonas aquatilis KCTC $2881^{\mathrm{T}}$ (Lee et al., 2001). -, Below detection limit; tr, trace amount $(<0.5 \%)$. For unsaturated fatty acids, the position of the double bond is located by counting from the methyl $(\omega)$ end of the carbon chain; cis and trans isomers are indicated by the suffixes $c$ and $t$, respectively. $\mathrm{C}_{17: 0}, \mathrm{C}_{17: 0}$ iso and $\mathrm{C}_{17: 1} \omega 5 c$ were below the detection limit in all strains.

\begin{tabular}{|c|c|c|c|c|c|c|c|c|}
\hline Fatty acid & 1 & 2 & 3 & 4 & 5 & 6 & 7 & 8 \\
\hline \multicolumn{9}{|l|}{ Saturated fatty acids } \\
\hline $\mathrm{C}_{14: 0}$ & - & 0.6 & 0.7 & 1.0 & 3.0 & 1.4 & 2.0 & 0.7 \\
\hline $\mathrm{C}_{15: 0}$ & - & 0.9 & 0.6 & - & - & 0.2 & - & - \\
\hline $\mathrm{C}_{16: 0}$ & 10.0 & 15.7 & 12.4 & 8.0 & 10.0 & 10.9 & 11.2 & 20.6 \\
\hline $\mathrm{C}_{18: 0}$ & - & - & - & $\operatorname{tr}$ & - & 0.5 & - & 1.0 \\
\hline $\mathrm{C}_{19: 0}$ cyclo $\omega 8 \mathrm{c}$ & - & - & - & - & - & - & 0.8 & - \\
\hline \multicolumn{9}{|c|}{ Unsaturated fatty acids } \\
\hline $\mathrm{C}_{16: 1}$ & - & - & - & - & 6.0 & 1.4 & 1.6 & 0.8 \\
\hline $\mathrm{C}_{16: 1} \omega 5 c$ & 4.0 & 2.4 & 3.8 & 3.0 & - & - & - & - \\
\hline $\mathrm{C}_{17: 1^{*}}$ & - & - & - & - & 1.0 & 1.7 & 2.6 & - \\
\hline $\mathrm{C}_{17: 1} \omega 6 c$ & 9.6 & 5.3 & 6.1 & $\operatorname{tr}$ & - & - & - & - \\
\hline $\mathrm{C}_{17: 1} \omega 8 c$ & - & 0.6 & 0.8 & - & - & - & - & - \\
\hline $\mathrm{C}_{18: 1} \omega 5 c$ & - & - & - & 1.0 & - & 1.8 & 1.0 & 1.5 \\
\hline \multicolumn{9}{|l|}{ Hydroxy fatty acids } \\
\hline $\mathrm{C}_{12: 0} 2-\mathrm{OH}$ & - & - & - & $\operatorname{tr}$ & - & - & 0.6 & - \\
\hline $\mathrm{C}_{14: 0} 2-\mathrm{OH}$ & - & - & - & 12.0 & 19.0 & 9.8 & 9.7 & 10.9 \\
\hline $\mathrm{C}_{15: 0} 2-\mathrm{OH}$ & - & - & - & $\operatorname{tr}$ & - & 0.3 & - & - \\
\hline $\mathrm{C}_{16: 0} 2-\mathrm{OH}$ & - & - & - & 1.0 & - & 0.8 & - & - \\
\hline $\mathrm{C}_{16: 0}$ iso $3-\mathrm{OH}$ & - & - & - & $\operatorname{tr}$ & - & - & - & - \\
\hline $\mathrm{C}_{16: 1} 2-\mathrm{OH}$ & - & - & - & $\operatorname{tr}$ & - & - & - & - \\
\hline $\mathrm{C}_{18: 1} 2-\mathrm{OH}$ & - & 0.9 & - & - & - & - & - & - \\
\hline \multicolumn{9}{|l|}{ Summed features $\dagger$} \\
\hline Summed feature 4 & 36.3 & 31.6 & 35.9 & 34.0 & - & 2.1 & 29.2 & 4.6 \\
\hline Summed feature 7 & 40.0 & 41.9 & 39.7 & 38.0 & 56.0 & 69.2 & 41.4 & 59.9 \\
\hline
\end{tabular}

*The position or stereochemistry of the double bond was not specified in these studies.

$\dagger$ Summed features are groups of two or three fatty acids that cannot be separated reliably by GLC with the MIDI system. Summed feature 4 contained $\mathrm{C}_{16: 1} \omega 7 c$ and/or $\mathrm{C}_{15: 0}$ iso 2-OH; summed feature 7 contained $\mathrm{C}_{18: 1} \omega 7 c / \omega 9 t / \omega 12 t$.

Strains PB56 ${ }^{\mathrm{T}}, \mathrm{PB} 180$ and PB229 showed cellular fatty acid profiles with large amounts of the saturated and unsaturated fatty acids $\mathrm{C}_{16: 0}(12.8 \%), \mathrm{C}_{16: 1}(3.2 \%), \mathrm{C}_{17: 1}(7.5 \%)$, summed feature $7 \quad\left(\mathrm{C}_{18: 1} \omega 7 c / \omega 9 t / \omega 12 t\right) \quad(41.0 \%)$ and summed feature $4\left(\mathrm{C}_{16: 1} \omega 7 c / \mathrm{C}_{15: 0}\right.$ iso $\left.2-\mathrm{OH}\right)(33.9 \%)$ (Table 2). No significant differences in the fatty acid profiles were found between the three isolates. There were some differences in FAME composition between these strains and their nearest phylogenetic neighbours in the genera Sphingomonas, Erythrobacter, Erythromicrobium and Porphyrobacter. The common dominant fatty acids for all strains are $\mathrm{C}_{16: 0}$ and summed feature 7 . Strains $\mathrm{PB} 56^{\mathrm{T}}$, PB180 and PB229 differ from the related Sphingomonas species with respect to the absence of 2-OH myristic acid $\left(\mathrm{C}_{14: 0} 2-\mathrm{OH}\right)$, which dominates the 2-hydroxy fatty acids in all other groups. 2-Hydroxy fatty acids are not completely absent in the novel isolates, however, since $\mathrm{C}_{18: 1} 2-\mathrm{OH}$ occurs in strain PB180 (Table 2). Furthermore, $\mathrm{C}_{15: 0}$ iso 2-OH (contained in summed feature 4 ) is potentially present in all three strains. Another conspicuous feature of strains $\mathrm{PB}^{\mathrm{T}}{ }^{\mathrm{T}}, \mathrm{PB} 180$ and PB229 is the large amount of fatty acids of summed feature $4\left(\mathrm{C}_{16: 1} \omega 7 c / \mathrm{C}_{15: 0}\right.$ iso 2-OH $)$, which has so far been found only in Sphingomonas faeni (Busse et al., 2003; Yabuuchi \& Kosako, 2005) and Sphingosinicella microcystinivorans $\mathrm{Y}^{\mathrm{T}}{ }^{\mathrm{T}}$ (Maruyama et al., 2006).

Isoprenoid quinones were extracted with chloroform/ methanol $(2: 1, \mathrm{v} / \mathrm{v})$ and purified by TLC on Merck silica gel $60 \mathrm{~F}_{254}$ plates $(20 \times 20 \mathrm{~cm}, 0.5 \mathrm{~cm}$ thick $)$ using a mixture of petroleum benzene and diethyl ether $(85: 15, \mathrm{v} / \mathrm{v})$ as the solvent. Spots were scraped off and then analysed by HPLC as described earlier (Collins \& Jones, 1981; Shin et al., 1996). The major isoprenoid quinone of isolates $\mathrm{PB} 56^{\mathrm{T}}, \mathrm{PB} 180$ and PB229 was ubiquinone Q-10, as in all known members of the Sphingomonadaceae (Rainey et al., 2003).

Within the genus Sphingomonas sensu stricto, only Sphingomonas (Blastomonas, Erythromonas) ursincola DSM $9006^{\mathrm{T}}$ and Sphingomonas (Blastomonas) natatoria DSM $3183^{\mathrm{T}}$ are currently known to be capable of synthesizing bacteriochlorophyll (BChl) $a$ (Yabuuchi \& Kosako, 2005). The other BChl a-containing members of the family Sphingomonadaceae are found within the genera Erythrobacter (Erythrobacter longus DSM $6997^{\mathrm{T}}$, Erythrobacter litoralis DSM $8509^{\mathrm{T}}$ ), Erythromicrobium [Erythromicrobium ramosum DSM 8510" , 'Erythromicrobium ezovicum' E-1, 'Erythromicrobium hydrolyticum' E4(1)] and Porphyrobacter (Porphyrobacter cryptus DSM $12079^{\mathrm{T}}$, P. dokdonensis DSM $17193^{\mathrm{T}}, P$. donghaensis DSM $16220^{\mathrm{T}}, P$. neustonensis DSM $9434^{\mathrm{T}}, P$. sanguineus ATCC $25659^{\mathrm{T}}$, P. tepidarius DSM $10594^{\mathrm{T}}$ ) and also include 'Citromicrobium bathyomarinum' JF-1, Sandaracinobacter sibiricus RB16-17 ${ }^{\mathrm{T}}$ and Sandarakinorhabdus limnophila so $42^{\mathrm{T}}$ (Hiraishi et al., 2002; Rainey et al., 2003; Yabuuchi \& Kosako, 2005; Gich \& Overmann, 2006; Yoon et al., 2004, 2006).

Using the $1.5 \mathrm{~kb}$ amplification product obtained for the pufLM genes (see above), the respective nucleotide sequences were determined and a phylogenetic tree was constructed as described for the 16S rRNA gene sequences. The pufLM gene sequences of strains PB56 ${ }^{\mathrm{T}}, \mathrm{PB} 180$ and PB229 were found to be most closely related to those of Sphingomonas (Blastomonas, Erythromonas) ursincola DSM $9006^{\mathrm{T}}$ and Sphingomonas (Blastomonas) natatoria DSM $3183^{\mathrm{T}}$ and to form a distinct lineage separate from all other species of the family Sphingomonadaceae, which is 


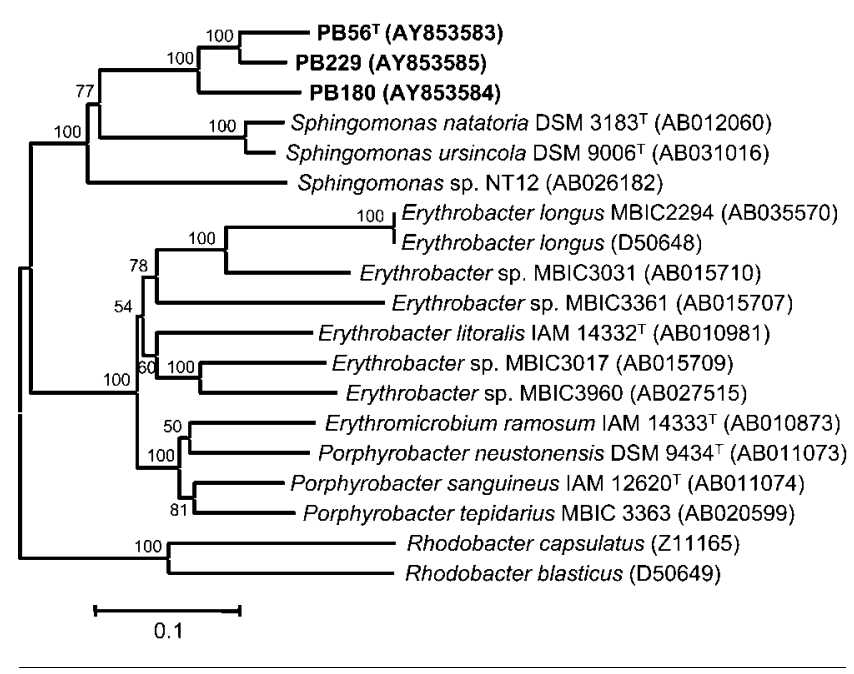

Fig. 2. Neighbour-joining tree showing the phylogenetic positions of strains $\mathrm{PB}^{\mathrm{T}}{ }^{\top}, \mathrm{PB} 180$ and $\mathrm{PB} 229$ and other related taxa based on pufL and pufM gene sequences. Bar, 0.1 substitutions per nucleotide position.

supported by high bootstrap resampling values (Fig. 2). The closer affiliation with the only BChl $a$-containing members of genus Sphingomonas sensu stricto rather than the other aerobic anoxygenic phototrophic genera is commensurate with the 16S rRNA gene phylogeny.

In order to test for the presence of BChl $a$ and to determine the carotenoid composition, pigments were extracted from cell pellets with methanol/acetone $(2: 7, \mathrm{v} / \mathrm{v})$ in the dark and consecutively analysed on an HPLC system equipped with a reversed-phase ET 250/8/4 Nucleosil 5 C18 PPN column (Macherey-Nagel) as described by Koblízek et al. (2003). Spectra were recorded by an absorption UV/Vis diode array detector and recorded at 450 and $770 \mathrm{~nm}$. At these wavelengths, absorbance coefficients used for quantification were $128.0 \mathrm{~mol} \mathrm{l}^{-1} \mathrm{~cm}^{-1}$ (Yurkov et al., 1994) for carotenoids and $54.8 \mathrm{~mol} \mathrm{l}^{-1} \mathrm{~cm}^{-1}$ for BChl a (Permentier et al., 2000), respectively. Excreted sulfated carotenoids were extracted directly from lyophilized culture supernatants. To remove the sulfate group, they were hydrolysed with $0.6 \mathrm{M} \mathrm{HCl}$ in tetrahydrofuran for $10 \mathrm{~min}$ at room temperature (http://lipidbank.jp/) and then subjected to HPLC analysis.

All strains produced numerous carotenoids. With the exception of spirilloxanthin and $\beta$-carotene, which constituted only minor amounts (peaks 12 and 14; see Supplementary Fig. S1 available in IJSEM Online), all other compounds differed from known carotenoids with respect to retention time and absorption spectrum (Supplementary Table S1). However, most carotenoids were ketocarotenoids, as indicated by their absorption spectra, which exhibited only one broad maximum (data not shown). The main carotenoid was a very polar xanthophyll sulfate (compound 2 in
Supplementary Fig. S1), but differed from erythroxanthin sulfate or caloxanthin sulfate produced by Erythrobacter longus and Erythromicrobium ramosum (Supplementary Table S1). The spectra of PB180 and PB229 were almost identical (Supplementary Fig. S1b), but differed from the spectrum of PB56 ${ }^{\mathrm{T}}$ (Supplementary Fig. S1a and Supplementary Table S1). Strains PB180 and PB229 released part of the sulfated carotenoid into the medium during growth. The excreted sulfated carotenoid corresponded to peak 2 of the cellular extract.

No BChl $a$ was detected in cells of strain PB56 ${ }^{\mathrm{T}}$, whereas cells of strains PB180 and PB229 contained small amounts of $\mathrm{BChl} a$. Aerobic anoxygenic photosynthetic bacteria analysed so far contain BChl $a$ esterified with phytol (BChl $a_{\mathrm{P}}$; Takaichi, 1999). Strain PB229 also had BChl $a_{\mathrm{P}}$ (Supplementary Fig. S1b, peak c). In addition, PB180 contained two more types of BChl $a$, tentatively identified as BChl $a$ esterified with farnesol (BChl $a_{\mathrm{F}}$; Supplementary Fig. S1b, peak a) and BChl $a$ esterified with geranylgeraniol (BChl $a_{\mathrm{GG}}$; Supplementary Fig. S1b, peak b) based on a comparison with pigment extracts from Rhodobacter capsulatus DSM 155 and from Rhodospirillum rubrum DSM 107. The ratio of BChl $a$ to cell dry weight ranged from 0.5 (strain PB229) to 12.2 (PB180) $\mu \mathrm{g} \mathrm{g}^{-1}$, depending on the medium composition and the illumination. The maximum cellular BChl a content in strain PB180 thus reached $6.4 \times$ $10^{-22}$ mol per cell, which is about 200 times lower than the average $\mathrm{BChl} a$ content of aerobic anoxygenic photosynthetic bacteria $\left(1.2 \times 10^{-19}\right.$ mol per cell; Jiao et al., 2003; Kolber et al., 2001). The ratio of BChl $a$ to carotenoids in the cells of strains PB180 and PB229 ranged from 1:60 to $1: 600$.

Strains PB56 ${ }^{\mathrm{T}}, \mathrm{PB} 180$ and PB229 thus differ clearly from Sphingomonas (Blastomonas) ursincola DSM $9006^{\mathrm{T}}$ and Sphingomonas natatoria DSM $3183^{\mathrm{T}}$ and from the type species of the aerobic anoxygenic phototrophic genera Sandaracinobacter, Erythrobacter, Erythromicrobium and Porphyrobacter in that they were non-motile, differed in colour, did not contain nostoxanthin and zeaxanthin and had no $\left(\mathrm{PB}^{\mathrm{T}}{ }^{\mathrm{T}}\right)$ or only trace amounts (PB180, PB229) of $\mathrm{BChl} a$. These morphological and physiological differences are in accordance with the sequence divergence of the respective $16 \mathrm{~S}$ rRNA and pufLM genes.

Based on the results of the present characterization, strains $\mathrm{PB}^{\mathrm{T}}{ }^{\mathrm{T}}, \mathrm{PB} 180$ and PB229 are classified as members of the genus Sphingomonas sensu stricto (Takeuchi et al., 2001). However, the three strains represent a separate phylogenetic lineage and exhibit considerable physiological differences from the recognized Sphingomonas species such as nonmotile cells, orange-red colour, lack of $\beta$-glucosidase and $\beta$-galactosidase, utilization of $\mathrm{D}$-mannitol, $\mathrm{L}$-serine and 4hydroxybenzoate and lack of 2-OH myristic acid. Therefore, strains PB56 ${ }^{\mathrm{T}}, \mathrm{PB} 180$ and $\mathrm{PB} 229$ are assigned to a novel species, for which the name Sphingomonas kaistensis sp. nov. is proposed. 


\section{Description of Sphingomonas kaistensis sp. nov.}

Sphingomonas kaistensis [ka.is.ten'sis. N.L. fem. adj. kaistensis of or pertaining to the Korea Advanced Institute of Science and Technology (KAIST)].

Cells are $0.7 \mu \mathrm{m}$ wide and $1.1 \mu \mathrm{m}$ long. Gram-negative, non-motile, non-spore-forming rods that grow aerobically. Colonies are circular, entire, low-convex, smooth, opaque and orange-red-coloured and grow chemo-organotrophically on R2A agar (Difco) without requirement for vitamins. All known strains contain two structural genes of the type II photosynthetic reaction centre ( $p u f L$ and $p u f M$ ), but BChl $a$ synthesis is detected in strains $\mathrm{PB} 180$ and $\mathrm{PB} 229$ only in very small amounts. Oxidase- and catalase-positive. Optimum temperature is $25-30^{\circ} \mathrm{C}$. Nitrate is not reduced to nitrite or $\mathrm{N}_{2}$. Indole is not produced. Strains are positive for enzyme activities of alkaline phosphatase, esterase (C4), esterase lipase (C8), leucine arylamidase and trypsin and negative for enzyme activities of arginine dihydrolase, lipase (C14), $N$-acetyl- $\beta$-glucosaminidase, protease (gelatin hydrolysis), urease, $\beta$-glucosidase (aesculin hydrolysis), $\alpha$-galactosidase, $\beta$-galactosidase (PNPG hydrolysis), $\beta$-glucuronidase, $\alpha$ fucosidase and $\alpha$-mannosidase. Strains do not grow on MacConkey agar. All strains utilize D-glucose, L-rhamnose, D-mannitol, $N$-acetylglucosamine, 4-hydroxybenzoate, L-proline, L-serine and glycogen. 2-Ketogluconate, 5-ketogluconate, acetate, propionate, valerate, citrate, lactate, phenylacetate, L-alanine and L-histidine are not utilized. The DNA base composition is $69.1-69.9 \mathrm{~mol} \% \mathrm{G}+\mathrm{C}$. The major isoprenoid quinone is ubiquinone Q-10 and major cellular fatty acids are $\mathrm{C}_{18: 1}$, summed feature $4\left(\mathrm{C}_{16: 1} \omega 7 \mathrm{cl}\right.$ $\mathrm{C}_{15: 0}$ iso 2-OH) and $\mathrm{C}_{16: 0}$, but cells lack any 2-hydroxy fatty acid.

The type strain is $\mathrm{PB}^{\mathrm{T}}{ }^{\mathrm{T}}\left(=\mathrm{KCTC} 12334^{\mathrm{T}}=\mathrm{DSM} 16846^{\mathrm{T}}\right)$, which was isolated from soil on the campus of KAIST in Daejeon city in South Korea.

\section{Acknowledgements}

This work was supported by the International Research Internship Program of the Korea Science and Engineering Foundation (KOSEF) to M. K. K. and a grant of the BMBF (Bundesministerium für Bildung, Wissenschaft, Forschung und Technologie) to J.O. (Biolog/ 01LC0021).

\section{References}

Altschul, S. F., Madden, T. L., Schäffer, A. A., Zhang, J., Zhang, Z., Miller, W. \& Lipman, D. J. (1997). Gapped BLAST and PSI-BLAST: a new generation of protein database search programs. Nucleic Acids Res 25, 3389-3402.

Buck, J. D. (1982). Nonstaining (KOH) method for determination of Gram reactions of marine bacteria. Appl Environ Microbiol 44, 992-993.

Busse, H.-J., Denner, E. B. M., Buczolits, S., Salkinoja-Salonen, M., Bennasar, A. \& Kämpfer, P. (2003). Sphingomonas aurantiaca sp. nov., Sphingomonas aerolata sp. nov. and Sphingomonas faeni sp. nov., air- and dustborne and Antarctic, orange-pigmented, psychrotolerant bacteria, and emended description of the genus Sphingomonas. Int J Syst Evol Microbiol 53, 1253-1260.

Busse, H.-J., Hauser, E. \& Kämpfer, P. (2005). Description of two novel species, Sphingomonas abaci sp. nov. and Sphingomonas panni sp. nov. Int J Syst Evol Microbiol 55, 2565-2569.

Collins, M. D. \& Jones, D. (1981). Distribution of isoprenoid quinone structural types in bacteria and their taxonomic implications. Microbiol Rev 45, 316-354.

Ezaki, T., Hashimoto, Y. \& Yabuuchi, E. (1989). Fluorometric deoxyribonucleic acid-deoxyribonucleic acid hybridization in microdilution wells as an alternative to membrane filter hybridization in which radioisotopes are used to determine genetic relatedness among bacterial strains. Int J Syst Bacteriol 39, 224-229.

Felsenstein, J. (1985). Confidence limit on phylogenies: an approach using the bootstrap. Evolution 39, 783-791.

Gich, F. \& Overmann, J. (2006). Sandarakinorhabdus limnophila gen. nov., sp. nov., a novel bacteriochlorophyll a-containing, obligately aerobic bacterium isolated from freshwater lakes. Int J Syst Evol Microbiol 56, 847-854.

Hiraishi, A., Yonemitsu, Y., Matsushita, M., Shin, Y. K., Kuraishi, H. \& Kawahara, K. (2002). Characterization of Porphyrobacter sanguineus sp. nov., an aerobic bacteriochlorophyll-containing bacterium capable of degrading biphenyl and dibenzofuran. Arch Microbiol 178, 45-52.

Jiao, N., Sieracki, M. E., Zhang, Y. \& Du, H. (2003). Aerobic anoxygenic phototrophic bacteria and their roles in marine ecosystems. Chin Sci Bull 48, 1064-1068 (in Chinese with English summary).

Kimura, M. (1983). The Neutral Theory of Molecular Evolution. Cambridge: Cambridge University Press.

Koblizek, M., Béjà, O., Bidigare, R. R., Christensen, S., BenitezNelson, B., Vetriani, C., Kolber, M. K., Falkowski, P. G. \& Kolber, Z. S. (2003). Isolation and characterization of Erythrobacter sp. strains from the upper ocean. Arch Microbiol 180, 327-338.

Kolber, Z. S., Plumley, F. G., Lang, A. S., Beatty, J. T., Blankenship, R. E., VanDover, C. L., Vetriani, C., Koblizek, M., Rathgeber, C. \& Falkowski, P. G. (2001). Contribution of aerobic photoheterotrophic bacteria to the carbon cycle in the ocean. Science 292, 2492-2495.

Kumar, S., Tamura, K., Jakobsen, I.-B. \& Nei, M. (2001). MEGA2: molecular evolutionary genetics analysis software. Bioinformatics $\mathbf{1 7}$, 1244-1245.

Lee, J.-S., Shin, Y. K., Yoon, J.-H., Takeuchi, M., Pyun, Y.-R. \& Park, Y.-H. (2001). Sphingomonas aquatilis sp. nov., Sphingomonas koreensis sp. nov. and Sphingomonas taejonensis sp. nov., yellow-pigmented bacteria isolated from natural mineral water. Int J Syst Evol Microbiol 51, 1491-1498.

Maruyama, T., Park, H.-D., Ozawa, K., Tanaka, Y., Sumino, T., Hamana, K., Hiraishi, A. \& Kato, K. (2006). Sphingosinicella microcystinivorans gen. nov., sp. nov., a microcystin-degrading bacterium. Int J Syst Evol Microbiol 56, 85-89.

Mesbah, M., Premachandran, U. \& Whitman, W. B. (1989). Precise measurement of the $\mathrm{G}+\mathrm{C}$ content of deoxyribonucleic acid by highperformance liquid chromatography. Int J Syst Bacteriol 39, 159-167.

Nagashima, K. V. P., Hiraishi, A., Shimada, K. \& Matsuura, K. (1997). Horizontal transfer of genes coding for the photosynthetic reaction centers of purple bacteria. J Mol Evol 45, 131-136.

Ohta, H., Hattori, R., Ushiba, Y., Mitsui, H., Ito, M., Watanabe, H., Tonosaki, A. \& Hatori, T. (2004). Sphingomonas oligophenolica sp. nov., a halo- and organo-sensitive oligotrophic bacterium from paddy soil that degrades phenolic acids at low concentrations. Int J Syst Evol Microbiol 54, 2185-2190.

Permentier, H. P., Schmidt, K. A., Kobayashi, M., Akiyama, M., Hager-Braun, C., Neerken, S., Miller, M. \& Amesz, J. (2000). Composition and optical properties of reaction center core 
complexes from the green sulfur bacteria Prosthecochloris aestuarii and Chlorobium tepidum. Photosynth Res 64, 27-39.

Rainey, F. A., Silva, J., Nobre, M. F., Silva, M. T. \& da Costa, M. S. (2003). Porphyrobacter cryptus sp. nov., a novel slightly thermophilic, aerobic, bacteriochlorophyll a-containing species. Int J Syst Evol Microbiol 53, 35-41.

Rosselló-Mora, R. \& Amann, R. (2001). The species concept for prokaryotes. FEMS Microbiol Rev 25, 39-67.

Saitou, N. \& Nei, M. (1987). The neighbor-joining method: a new method for reconstructing phylogenetic trees. Mol Biol Evol 4, 406-425.

Sasser, M. (1990). Identification of bacteria by gas chromatography of cellular fatty acids. MIDI Technical Note 101. Newark, DE: MIDI Inc.

Shin, Y. K., Lee, J.-S., Chun, C. O., Kim, H.-J. \& Park, Y.-H. (1996). Isoprenoid quinone profiles of the Leclercia adecarboxylata KCTC $1036^{\mathrm{T}}$. J Microbiol Biotechnol 6, 68-69.

Takaichi, S. (1999). Carotenoids and carotenogenesis in anoxygenic photosynthetic bacteria. In Advances in Photosynthesis, vol. 8, The Photochemistry of Carotenoids, pp. 39-69. Edited by H. A. Frank, A. J. Young, G. Britton \& R. J. Cogdell. Dordrecht: Kluwer.

Takeuchi, M., Sakane, T., Yanagi, M., Yamasato, K., Hamana, K. \& Yokota, A. (1995). Taxonomic study of bacteria isolated from plants: proposal of Sphingomonas rosa sp. nov., Sphingomonas pruni sp. nov., Sphingomonas asaccharolytica sp. nov., and Sphingomonas mali sp. nov. Int J Syst Bacteriol 45, 334-341.

Takeuchi, M., Hamana, K. \& Hiraishi, A. (2001). Proposal of the genus Sphingomonas sensu stricto and three new genera, Sphingobium, Novosphingobium and Sphingopyxis, on the basis of phylogenetic and chemotaxonomic analyses. Int J Syst Evol Microbiol 51, 1405-1417.

Tamaoka, J. \& Komagata, K. (1984). Determination of DNA base composition by reversed phase high-performance liquid chromatography. FEMS Microbiol Lett 25, 125-128.

Thompson, J. D., Gibson, T. J., Plewniak, F., Jeanmougin, F. \& Higgins, D. G. (1997). The CLUSTAL_X windows interface: flexible strategies for multiple sequence alignment aided by quality analysis tools. Nucleic Acids Res 25, 4876-4882.

Yabuuchi, E. \& Kosako, Y. (2005). Order IV. Sphingomonadales ord. nov. In Bergey's Manual of Systematic Bacteriology, 2nd edn, vol. 2, part C, pp. 230-233. Edited by D. J. Brenner, N. R. Krieg, J. T. Staley \& G. M. Garrity. New York: Springer.

Yabuuchi, E., Kosako, Y., Fujiwara, N., Naka, T., Matsunaga, I., Ogura, H. \& Kobayashi, K. (2002). Emendation of the genus Sphingomonas Yabuuchi et al. 1990 and junior objective synonymy of the species of three genera, Sphingobium, Novosphingobium and Sphingopyxis, in conjunction with Blastomonas ursincola. Int J Syst Evol Microbiol 52, 1485-1496.

Yoon, J.-H., Lee, S.-T., Kim, S.-B., Kim, W. Y., Goodfellow, M. \& Park, Y.-H. (1997). Restriction fragment length polymorphism analysis of PCR-amplified $16 \mathrm{~S}$ ribosomal DNA for rapid identification of Saccharomonospora strains. Int J Syst Bacteriol 47, 111-114.

Yoon, J.-H., Lee, S. T. \& Park, Y.-H. (1998). Inter- and intraspecific phylogenetic analysis of genus Nocardioides and related taxa based on $16 \mathrm{~S}$ rDNA sequences. Int J Syst Bacteriol 48, 187-194.

Yoon, J.-H., Lee, M.-H. \& Oh, T.-K. (2004). Porphyrobacter donghaensis sp. nov., isolated from sea water of the East Sea in Korea. Int J Syst Evol Microbiol 54, 2231-2235.

Yoon, J.-H., Kang, S.-J., Lee, M.-H., Oh, H. W. \& Oh, T.-K. (2006). Porphyrobacter dokdonensis sp. nov., isolated from sea water. Int J Syst Evol Microbiol 56, 1079-1083.

Yun, N. R., Shin, Y. K., Hwang, S. Y., Kuraishi, H., Sugiyama, J. \& Kawahara, K. (2000). Chemotaxonomic and phylogenetic analyses of Sphingomonas strains isolated from ears of plants in the family Gramineae and a proposal of Sphingomonas roseiflava sp. nov. J Gen Appl Microbiol 46, 9-18.

Yurkov, V., Stackebrandt, E., Holmes, A., Fuerst, J. A., Hugenholtz, P., Golecki, J., Gad'on, N., Gorlenko, V. M., Kompantseva, E. I. \& Drews, G. (1994). Phylogenetic positions of novel aerobic, bacteriochlorophyll a-containing bacteria and description of Roseococcus thiosulfatophilus gen. nov., sp. nov., Erythromicrobium ramosum gen. nov., sp. nov. and Erythrobacter litoralis sp. nov. Int J Syst Bacteriol 44, 427-434.

Yurkov, V., Stackebrandt, E., Buss, O., Vermeglio, A., Gorlenko, V. \& Beatty, J. T. (1997). Reorganization of the genus Erythromicrobium: description of 'Erythromicrobium sibiricum' as Sandaracinobacter sibiricus gen. nov., sp. nov., and of 'Erythromicrobium ursincola' as Erythromonas ursincola gen. nov., sp. nov. Int J Syst Bacteriol 47, $1172-1178$. 